\title{
Pros and cons for the role of air pollution on COVID-19 development
}

\author{
Isabella Annesi-Maesano ${ }^{1}$, Cara Maesano ${ }^{1}$, maria D'Amato ${ }^{2}$, and Gennaro D'Amato ${ }^{3}$ \\ ${ }^{1}$ INSERM and Sorbonne University \\ ${ }^{2}$ Division of Pneumophthisiology 1 \\ ${ }^{3}$ Division of Pneumology and Allergology High Speciality "A.Cardarelli"
}

December 20, 2020

\section{Hosted file}

AIR POLLUTION AND COVID 19 PROS AND CONS_Amended.pdf available at https://authorea.com/ users/323357/articles/499754-pros-and-cons-for-the-role-of-air-pollution-on-covid-19development

\section{Hosted file}

Figure for Allergy.pptx available at https://authorea.com/users/323357/articles/499754-prosand-cons-for-the-role-of-air-pollution-on-covid-19-development 